\title{
Lectio praecursoria
}

\section{Lasten vertaissuhdetaitojen kehittäminen - näkökulmia kiusaamisen ehkäisemiseen}

\author{
Vilja Laaksonen
}

Lectio praecursoria puheviestinnän väitöskirjaksi tarkoitetun tutkimuksen Lasten vertaissuhdetaidot ja kiusaaminen esikoulun vertaisryhmissä tarkastustilaisuudessa Jyväskylän yliopistossa 25.1.2014. Vastaväittäjänä toimi dosentti Elina Kontu (Helsingin yliopisto) ja kustoksena dosentti, yliopistonlehtori Maili Pörhölä.

Lasten hyvinvointi ja pärjääminen omassa vertaisryhmässään ovat teemoja, jotka herättävät tunteita. Aikuiset katsovat lasten leikkejä ulkopuolisen perspektiivistä. Vanhemmat, opettajat, isovanhemmat, kummit, isommat sisarukset - oli rooli mikä tahansa, mieltä polttavat kysymykset ovat usein samoja. Miten me aikuiset voimme tukea lapsen tasapainoista kehitystä? Millaisia taitoja lapset tarvitsevat, jotta he pärjäävät elämässä? Miten me tuemme näiden elämässä tärkeiden taitojen kehitystä?

Samaan aikaan kun aikuiset miettivät lapsen hyvinvointia ja tarkkailevat lapsen elämää pitkäjänteisen kehityksen näkökulmasta, lapset ovat kiinni tässä päivässä. Pienten lasten vertaissuhteet rakentuvat pitkälti leikin ympärille. Leikkiessä lapsi ottaa osaa omaan vertaismaailmaansa. Kavereiden kanssa toimiminen, oman mielipiteen esiin tuominen ja toisten huomioon ottaminen ovat taitoja, joita opitaan ja harjoitellaan vertaisten kanssa. Leikin myötä lapsi toteuttaa ideoitaan, oppii uusia asioita ja tutustuu uusiin kavereihin.

Leikki ei ole lapsille vain leikkiä. Vertaisryhmän torjunta sulkee oven lasten arkipäivään ja sosiaaliseen maailmaan. Kuten eräs tutkimuksessa haastateltu lapsi sanoi: "Mä tykkään niinku olla sillein laumassa. Mä vähän pelkään yksinäisyyttä." Tai kuten toinen lapsi toi esiin: "On paljon hauskempaa leikkiä kavereitten kanssa, koska yksin voi tulla äitiäkin ikävä."

Päiväkoti tarjoaa usein ensimmäisen laajan vertaisyhteisön, jossa lapsi muodostaa erilaisia vuorovaikutussuhteita useisiin ikätovereihin. Suomessa päivähoidossa tai koulussa järjestettävään esiopetukseen osallistuu jo 
noin 98 \% ikäluokan lapsista. Lähes kaikilla koulutaipaleensa aloittavilla on siis kokemuksia vertaisten parissa toimimisesta ja käsityksiä itsestään vertaisryhmän jäsenenä.

Kavereiden kanssa toimiminen edellyttää vertaissuhdetaitoja, ja yhteiset leikit puolestaan vahvistavat yhteenkuuluvuuden tunnetta. Lapsi oppii vuorovaikutuksessa toisten lasten kanssa neuvottelemaan leikin säännöistä, odottamaan omaa vuoroaan ja ottamaan uusia kavereita mukaan leikkiin. Näin voidaan nähdä, että monet myöhemmin elämässä tarvittavat vuorovaikutustaidot ovat läsnä myös alle kouluikäisten lasten vertaissuhteissa. Lapset oppivat ja harjoittelevat näitä taitoja tasapainoisissa vertaissuhteissa. Parhaimmillaan vertaisten parissa toimiminen tukee lapsen sosioemotionaalista kehitystä ja tarjoaa valmiuksia solmia uusia kaverisuhteita.

Valitettavasti kaikki vertaissuhteet eivät kuitenkaan ole palkitsevia lapsen kehityksen kannalta. Pelko, turvattomuus ja yksinäisyys koskettavat myös esikouluikäisiä lapsia. Jo alle kouluikäiset lapset kiusaavat ja torjuvat toisia lapsia. Kiusaamisella tarkoitetaan tässä tutkimuksessa haitallista ja epätasapainoista vuorovaikutusprosessia, jossa lapsi on toistuvasti yhden tai useamman vertaisen loukkaamisen, satuttamisen tai torjumisen kohteena pystymättä puolustautumaan tai vaikuttamaan saamaansa kohteluun.

Vertaisryhmän torjunta voi vaarantaa lapsen sosioemotionaalisen kehityksen ja samalla estää vertaissuhdetaitojen tyypillisen kehittymisen. Lisäksi aiemmat tutkimukset ovat osoittaneet, että kiusaamisroolit ovat suhteellisen pysyviä jo alakoulusta yläkouluun siirryttäessä. Riskinä on, että päiväkodissa opitut roolit, haitalliset käyttäytymismallit ja huono itsetunto seuraavat lasta koulutaipaleelle.

Lasten vertaissuhdetaidot ja niiden merkitys esikouluikäisten kiusaamisprosesseissa ovat väitöskirjatutkimukseni keskiössä. Tämän työn keskeisenä näkökulmana on ollut, että vertaissuhdetaitojen yksilöllinen ja systemaattinen kehittäminen voisi ehkäistä kiusaamista. Näin mahdollisen kiusaamis- ja syrjäytymiskierteen syntyminen voitaisiin katkaista jo varhaisessa vaiheessa.

\section{Monimetodinen tutkimusasetelma jakaantui viiteen tutkimustehtävään}

Olen tässä työssä tutkinut esikouluikäisten lasten vertaissuhdetaitoja ja kiusaamista esikoulun vertaisryhmissä. Päädyin monimetodiseen tutkimusasetelmaan, joka auttoi lähestymään monisäkeistä ja vähän tutkittua tutkimusilmiötä. Keräsin tutkimuksen empiirisen aineiston viidessä 
päiväkodissa syksyllä 2010. Tutkimusaineisto koostuu lasten havainnoinnista ja haastatteluista sekä tutkija- ja opettaja-arvioijien täyttämistä arviointilomakkeista. Tutkimukseen osallistui yhteensä 72 esikouluikäistä eli 5-6-vuotiasta lasta.

Tällä väitöskirjatutkimuksella oli viisi tutkimustehtävää. Ensimmäisenä tavoitteena oli kartoittaa ja selvittää, millaisia lasten vertaissuhdetaidot ovat tutkimuksen kohteena ja millaisia yhteyksiä tutkimuskirjallisuudessa on tunnistettu vertaissuhdetaitojen ja vertaisryhmän dynamiikan välillä. Tähän taustoittavaan kysymykseen etsittiin vastausta kahden monitieteisen ja systemaattisen kirjallisuuskatsauksen avulla.

Toisena tavoitteena oli kuvata, millaisia lasten vertaissuhdetaidot ovat ja miten niitä arvioidaan. Tähän tutkimustehtävään etsittiin vastausta tutkimalla lasten vertaissuhdetaitojen rakennetta ja arvioimalla lasten vertaissuhdetaitojen tasoa. Arviointi pohjasi viidessä päiväkodissa toteutettuun havainnointiin sekä opettaja- ja tutkija-arvioijan täyttämiin arviointilomakkeisiin.

Kolmanneksi tämän työn tavoitteena oli selvittää, kuinka yhdenmukaisesti eri tietolähteet tunnistavat lasten kiusaamisrooleja ja miten lapset kuvaavat kiusaamista ja sen syitä. Lasten kiusaamisroolit määräytyivät kolmen tietolähteen perusteella eli näkemystä kysyttiin lapselta itseltään, opettajalta ja tutkijalta. Lasten kiusaamiskertomukset auttoivat näkemään kiusaamisilmiön lasten silmin.

Neljänneksi tavoitteena oli tunnistaa ja kuvata lapsen vuorovaikutuskäyttäytymisen ja vertaissuhdetaitojen yhteyksiä lapsen käyttäytymiseen kiusaamisprosesseissa. Tähän tehtävään etsittiin vastausta yhdistämällä lapsen vertaissuhdetaitojen tasosta ja lapsen kiusaamisroolista saatuja tuloksia toisiinsa.

Viidenneksi tutkimuksessa jalostettiin etenkin lastentarhanopettajien käyttöön suunnattua Lapsen vertaissuhdetaitojen arviointi -mittaria. Tavoitteena oli tarjota konkreettinen työkalu ja selkeitä arviointikriteerejä, jotka tukevat opettajien valmiuksia lasten vertaissuhdetaitojen arvioimiseen ja kehittämiseen.

\section{Työn tulokset raportoitiin väitöskirjan viidessä artikkelissa}

Ensimmäiseen tutkimustehtävään etsittiin vastausta monitieteisen ja systemaattisen kirjallisuuskatsauksen avulla. Tulokset osoittivat, että lasten vuorovaikutustaidoista oli tyypillisimmin käytetty jotain seuraavaa käsitettä: sosiaalinen kompetenssi, sosiaaliset taidot, viestintätaidot ja vertaissuhdetaidot. Kirjallisuuskatsaus tuki tämän tutkimuksen käsite- 
valintaa. Tässä väitöskirjassa päädyttiin käyttämään vertaissuhdetaitojen käsitettä, joka rajaa tarkastelun juuri vertaisten parissa tarvittaviin vuorovaikutustaitoihin.

Lisäksi tulokset osoittivat, että lasten vuorovaikutustaitojen kehitystä voidaan tarkastella positiivisen ja negatiivisen kierteen avulla. Siinä missä vertaisryhmän hyväksymä lapsi pääsee yhä useammin harjoittelemaan vuorovaikutustaitoja leikeissä kavereiden kanssa, jää vertaisryhmän torjuma lapsi vaille näitä kokemuksia. Näin vertaisryhmän torjunta voi vaarantaa vuorovaikutustaitojen kehittymisen ja siten heikentää lapsen mahdollisuuksia aktiiviseen toimijuuteen omassa vertaisryhmässään.

Toiseen tutkimustehtävään etsittiin vastausta empiirisen aineiston pohjalta. Tulosten perusteella lasten vertaissuhdetaidot voidaan jakaa neljään osa-alueeseen, jotka lapset hallitsevat vaihtelevasti: tilanteenmukaisen vuorovaikutuskäyttäytymisen taidot, vuorovaikutuksen ylläpitämisen ja vertaisten tukemisen taidot, vuorovaikutukseen liittymisen taidot sekä toisten huomioon ottamisen taidot.

Tulosten perusteella lapsilla oli kohtuullisen hyvät tilanteenmukaisen vuorovaikutuskäyttäytymisen taidot eli he hallitsevat esimerkiksi opetustilanteessa tarvittavat vertaissuhdetaidot. Toisaalta lapsilla oli vaikeuksia etenkin vuorovaikutuksen ylläpitämisen ja vertaisten tukemisen taidoissa. Tämä tarkoittaa, että heillä oli haasteita esimerkiksi konfliktinhallinnassa sekä palautteen antamisessa ja vastaanottamisessa. Yksittäisten lasten taitotaso vaihteli heikosta erittäin hyvään. On myös hyvä korostaa, että lapsella voi olla puutteita yhdessä osa-alueessa ja vahvuuksia toisessa.

Kolmannessa tutkimustehtävässä selvitettiin lasten rooleja kiusaamisprosesseissa. Tunnistuksen perusteella lapset jaettiin neljään ryhmään: kiusaajiin, kiusattuihin, kiusaaja-uhreihin ja ei osallisena oleviin lapsiin. Lapset nimesivät kiusaamiseksi esimerkiksi lyömisen, potkimisen, leikin ulkopuolelle jättämisen, haukkumisen ja kamppaamisen. Kiusaamista kuvattiin myös "epämiellyttävänä leikkinä" ja osa lapsista teki eron "tahallaan" ja "leikillään" kiusaamisen välillä. Tämä tuo selkeän haasteen opettajille ja vanhemmille, joiden voi olla vaikea tunnistaa tätä eroa.

Neljännen tutkimustehtävän tavoitteena oli yhdistää lasten vertaissuhdetaidoista ja kiusaamisrooleista saatu tutkimustieto toisiinsa. Analyysi osoitti, että kiusaajalle tyypillistä vuorovaikutuskäyttäytymistä kuvattiin määrääväksi ja muita syrjiväksi. Kiusattujen vuorovaikutuskäyttäytymistä kuvattiin puolestaan syrjäänvetäytyväksi ja kyvyttömäksi puolustautumaan. Kiusaaja-uhreille tyypillinen vuorovaikutuskäyttäytyminen tyypiteltiin häiritsevän ja aggressiivisen alle. Ei osallisena olevien lasten vuorovaikutuskäyttäytymistä kuvattiin puolestaan toisia tukevaksi ja kaikkien kanssa leikkiväksi. 
Nämä erot näkyivät myös vertaissuhdetaitojen tasossa. Lasten vertaissuhdetaitojen ja kiusaamisen välisen yhteyden tarkastelu osoitti, että kiusaamisessa osallisena olevilla lapsilla oli huomattavia puutteita vertaissuhdetaidoissa. Kiusaajien, kiusattujen ja kiusaaja-uhrien vertaissuhdetaidot arvioitiin tyypillisesti kohtalaisiksi, kun taas kiusaamistilanteiden ulkopuolelle jäävien lasten vertaissuhdetaidot arviointiin hyvälle tasolle. Erot ryhmien välillä olivat merkitseviä.

Tulosten perusteella kiusaajiksi luokitelluilla lapsilla oli haasteita etenkin toisten huomioon ottamisen taidoissa, kiusatuilla oli vaikeuksia vuorovaikutukseen liittymisen taidoissa ja kiusaaja-uhrit eivät puolestaan hallinneet vuorovaikutuksen ylläpitämisen ja vertaisten tukemisen taitoja. Tulosten perusteella kiusaajilla oli vahvemmat vertaissuhdetaidot kuin kiusatuilla ja kiusaaja-uhreilla. Toisaalta kiusaajilla oli vaikeuksia kompromissien tekemisessä ja loukkaamisen välttämisessä. Voi olla, että nämä taidot selittävät osaltaan empatiakykyä.

Viides tutkimustehtävä oli käytännönläheinen ja tavoitteena oli kehittää konkreettisia työkaluja, jotka tukevat lasten vertaissuhdetaitojen kehittämistä yksilöllisestä näkökulmasta. On tärkeää, että päiväkodin henkilökunnalla on mahdollisuuksia vertaissuhdetaitojen arviointiin ja välineitä niiden systemaattiseen kehittämiseen. Tätä tavoitetta ajatelleen työssä on kehitetty Lapsen vertaissuhdetaitojen arviointi -työkalu (2014), joka soveltuu etenkin 4-8-vuotiaiden lasten vertaissuhdetaitojen arviointiin. Lapsen tasapainoisen kehityksen tukeminen ja toimijuuden vahvistaminen lähtevät siitä, että tunnistetaan lapsen vahvuudet samoin kuin ne alueet, joissa lapsi tarvitsee erityistä tukea. Näin lapsi kohdataan omana ainutlaatuisena itsenään.

\section{Vertaissuhdetaitojen kehittämisestä työkaluja kiusaamisen ehkäisemiseen}

Käytännönläheisyys ja tulosten sovellettavuus ovat ohjanneet väitöskirjaprosessia sen alkumetreiltä saakka. Tutkimustulokset eivät sinänsä muuta maailmaa, jos niiden tuottamaa ymmärrystä ei jalkauteta osaksi päiväkodin arkea. Tavoitteena on, että tämän väitöskirjatutkimuksen tuottamaa tietoa lasten vertaissuhdetaidoista ja kiusaamisesta esikoulun vertaissuhteissa voidaan hyödyntää osana varhaiskasvatuksen suunnittelua ja sen toteutusta.

Monimetodinen tutkimusasetelma tuki tutkimuksen tavoitteiden saavuttamista. Vaikka tutkimustulokset ovat osin sidoksissa esikoulukontekstiin, voidaan työn tuottamaa ymmärrystä lasten vertaissuhdetaidoista 
soveltaa myös esikouluikäisiä nuorempiin ja vanhempiin lapsiin. Mitä varhaisemmassa vaiheessa lapset pääsevät vahvistamaan vertaissuhdetaitoja, sen paremmat valmiudet heillä on ihmissuhteiden muodostamiseen ja ylläpitämiseen jatkossa. Haasteena on, miten yksilöllisiin vahvuuksiin ja kehityskohteisiin kiinnittyvä taitoharjoittelu viedään yleiselle tasolle.

Työssä nostettiin esiin myös kiusaamisen ehkäisemiseen tähtääviä näkökulmia. Näistä moni kytkeytyy siihen, että lapsen kehityksen tukeminen lähtee lapsen maailmasta käsin. Jatkotutkimusta kaivataan myös vertaissuhdetaitojen kehityksen tukemisesta ja kiusaamiseen puuttumisesta. Jatkotutkimuksessa olisi myös kiinnostavaa tarkastella yksityiskohtaisemmin vertaissuhdetaitojen ja kiusaamisroolien, kuten puolustajien ja avustajien, yhteyksiä laajemmalla aineistolla.

On hyvä muistaa, että kiusaamisen ulkopuolella olevat lapset ovat osa vertaisryhmää, jossa sallitaan ja ylläpidetään kiusaamista. Näin on tärkeää, että kiusaamisen ehkäisemisessä huomioidaan koko lapsiryhmä.

Kiusaaminen pienten lasten vertaissuhteissa on haastava tutkimusaihe, joka herättää tunteita. Voiko pienten lasten ristiriitoja, kahnauksia ja leikin ulkopuolelle jättämistä kutsua kiusaamiseksi? Eikö kiusaamisroolien tunnistaminen stigmatisoi pienet lapset? Entä eikö taitoharjoittelusta puhuminen ole normatiivista ja kiusatun tunteita väheksyvää?

On syytä korostaa, etteivät syyllistäminen tai rangaistukset yksin poista kiusaamista. Vertaissuhdetaitojen kehittäminen avaa enemmän ovia kuin rangaistusten jakaminen. Kiusaamisen ehkäiseminen ja siihen puuttuminen edellyttää, että ilmiöstä puhutaan avoimesti. Yhtä lailla vertaissuhdetaitojen arvioinnin tarkoituksena ei ole arvottaa lapsia toisiinsa nähden tai valaa heitä yhteen muottiin. Lapsen tasapainoisen kehityksen tukeminen lähtee siitä, että tunnistetaan persoonalliset vahvuudet ja alueet, joissa lapsi tarvitsee erityistä tukea.

Ei ole olemassa täydellistä viestijää. Taitoja voi kuitenkin oppia ja harjoittaa, jotta lapset osaavat toimia erilaisissa viestintätilanteissa. Opettaja ja vanhempi voi tukea lapsen toimijuutta esimerkiksi kannustajan, kuuntelijan, rohkaisijan ja neuvojan roolissa. Kun keskusteluyhteys on auki sekä vanhempien että opettajien suuntaan, lapsen on helpompi kertoa kiusaamistilanteista. Siten aikuiset voivat puuttua ja kannustaa lapsia puuttumaan kiusaamiseen. Lapset oppivat sosiaalisen maailman pelisääntöjä keskusteluiden ja esimerkkien avulla. Siksi lasten vertaisryhmässä on hyvä käydä avointa keskustelua muun muassa vertaisten kanssa toimimisesta, toisten huomioimisesta ja kiusaamisesta. Näin me voimme tarjota lapsille mahdollisimman hyvät valmiudet yhdessä toimimiseen. 